\title{
PENGARUH JUMLAH KOMPOSIT BATUAN TERHADAP KESTABILAN LERENG TAMBANG TERBUKA BATUBARA MULTI LAPISAN MENGGUNAKAN METODE ELEMEN HINGGA 3 DIMENSI
}

\author{
M Kemal Ghifari, Masagus Ahmad Azizi, Irfan Marwanza, Afiat Anugrahadi
}

Prodi Teknik Pertambangan FTKE Universitas Trisakti

Email: Muhmmadkemalghifari@gmail.com; masagus.azizi@trisakti.ac.id;

Irfanm@trisakti.ac.id; afiat@trisakti.ac.id

\begin{abstract}
ABSTRAK
PT. X memiliki disain rencana tambang (pit plan) tahun 2020, yang memerlukan analisis kestabilan lereng guna mengoptimasi cadangan batubara tertambang dan keselamatan operasi penambangan. Pada penelitian ini, analisis kestabilan lereng menggunakan metode elemen hingga (MEH) 3 dimensi. Di samping itu juga dilakukan analisis probabilistik guna memvalidasi hasil perhitungan MEH 3 dimensi. Kompleksitas lapisan batuan yang cukup banyak pada tambang MIP memberikan kesulitan dalam memodelkan dalam analisis 3D menggunakan MEH. Oleh sebab itu digunakan pendekatan pembobotan parameter karakteristik batuan dalam menelaah keakurasian hasil perhitungan faktor keamanan (FK) dan penentuan lokasi lereng kritis. Secara praktis pendekatan pembobotan ini sudah diterapkan di sejumlah tambang batubara di Indonesia, namun terbatas pada analisis 2D. Oleh sebab itu hasil penelitian ini menjadi suatu pencapaian penting yang dapat disosialisasikan dan diaplikasikan oleh para praktisi geoteknik tambang di Indonesia
\end{abstract}

Key words: Tambang Terbuka, kestabilan lereng, metode elemen hingga 3D, batubara

\section{A. LATAR BELAKANG}

PT X adalah pemegang PKP2B penambangan terbuka batubara yang terletak di 2 kecamatan yakni Sembakung dan Sesayap Hilir, serta 2 Kabupaten yakni Nunukan dan Tana Tidung, Kalimantan Utara, Indonesia. Dalam melakukan kegiatan operasi penambangannya, PT X telah merancang geometri lereng tambang hingga akhir tahun 2020. Untuk memastikan disain rancangan tersebut stabil, maka dilakukan analisis kestabilan lereng 3 dimensi metode elemen hingga (MEH) untuk menzonasi daerah yang paling kritis, serta dilanjutkan dengan analisis 2 dimensi untuk memvalidasi nilai SRF yang didapatkan. Nilai SRF dan total diplacement menentukan daerah mana yang paling kritis dan berbahaya.

Dalam menganalisa 3 dimensi didapatkan kendala dalam memodelkan lapisannya, dikarenakan untuk lapisan banyak dan tipis fitur pembagian geometri RS3 dapat memecah geometri kecil menjadi berdiri sendiri sehingga membuat beban memori menjadi lebih besar dan membuat software tidak dapat melakukan komputasi, sehingga perlu dilakukannya penyederhanaan banyak lapisan menjadi beberapa lapisan (composite) dengan cara pembobotan terhadap nilai properties batuan penyusun composite berdasarkan ketebalannya.

Metodologi pembobotan terhadap nilai properties composite ini diharapkan dapat berguna bagi para praktisi geoteknik industri tambang di Indonesia. 


\section{B. TEORI}

\section{B.1 Elemen Hingga 3 Dimensi}

Analisis geoteknik secara Elasto-Plastic dengan menggunakan metode elemen hingga (MEH ) telah diterima secara luas didalam dunia penelitian, Ulasan Duncan's tentang analisis MEH pada lereng tambang terbuka terkonsentrasi terutama pada deformasi yang bekerja, Penggunaan MEH dalam analisis stabilitas lereng selanjutnya telah dikembangkan lebih lanjut (mis. Grifoths, 1989; Potts et al., 1990; Matsui \& San, 1992), Wong (1984).

Dalam menganalisa dengan $\mathrm{MEH}$, node digunakan sebagai titik dasar acuan yang saling berhubungan pada elemen penyusun dari bidang yang akan dianalisa, node ini selanjutnya bergerak ke arah $\mathrm{x}$ dan y saat parameter kuat batuan diturunkan pada 3 dimensi ditambah sumbu $\mathrm{z}$, perpindahan dari node ini disebut displacement dan dapat dihitung pada hasil akhir perhitungan, arah dari pergerakan vector nodenya didapatkan dari hasil iterasi perhitungan matriks teganganregangan baik itu arah $\mathrm{x}$, y maupun z. Pada analisis 3 dimensi nilai displacement akan memberikan informasi mengenai daerah yang paling kritits.

Analisa secara 3 dimensi umumnya memiliki nilai faktor keamanan yang lebih tinggi dibandingkan analisis secara 2 dimensi Hutchinson \& Sarma (1985) and Hungr (1987). Analisis yang dilakukan secara 3 dimensi lebih baik dalam memodelkan secara geometri lereng sehingga hasil yang didaptkan lebih realistis dibandingkan dengan analisis yang hanya dilakukan secara 2 dimensi.

Hasil analisis perbandingan nilai SRF yang dilakukan secara 2 dimensi dengan 3 dimensi yang dilakuakn oleh (jie-qun dan jin-loeng, 2012) memberikan hasil perbandingan SRF sebesar 1.547 untuk analisis secara 2 dimensi dan SRF sebesar 1.579 untuk hasil analisis secara 3 dimensi, nilai yang didapatkan sangat dekat namun hasil yang didapatkan 2 dimensi lebih pesismis dibandingkan dengan 3 dimensi, namun hasil model yang diberikan oleh 3 dimensi lebih baik dibandingkan dengan 2 dimensi dalam hal hasil analisis seperti (total displacement, nodes vector deformation, $\sigma 3, \sigma 1 \mathrm{dll})$.

\section{B.2 Konsep Kestabilan Lereng}

Konsep dari kestabilan suatu bukaan lereng dapat diukur dari besaran nilai FK yang dimiliki oleh lereng tersebut, nilai dari faktor keamanan lereng dapat dihitung berdasarkan perbandingan antara gaya-gaya yang bekerja pada bidang gelincirnya dimana bidang permukaan tersebut yang berpotensi menyebabkan terjadinya longsoran pada lereng tersebut.

Faktor keamanan dari suatu bukaan lereng dapat ditentukan berdasarkan perbandingan gaya penggerak dan gaya penahan yang bekerja pada permukaan bidang gelincir padang lereng tersebut, perhitungan faktor keamanan diperkenalkan pertama kali oleh Fellenius yang mana dikembangkan oleh (Lambe \& Whitman, 1969) dimana gaya penahan adalah besarnya kuat geser yang dimiliki oleh batuan atau tanah tersebut sedangkan gaya penggerak didapat berdasarkan penguraian dari gaya-gaya yang bekerja disepanjang bidang longsornya.

Tidak perlu membuat asumsi bentuk dan posisi bidang gelincir pada $\mathrm{MEH}$, kegagalan terjadi pada zona di mana kekuatan geser batuan atau tanah tidak dapat mempertahankan tegangan geser yang bekerja konsep inilah yang selanjutnya digunakan pada (SRF) atau Strength Reduction Factor, dimana pada metode tersebut dilakukan pengurangan terhadap parameter kuat geser batuan sampai lereng mengalami keruntuhan (non-convergence). Saat iterasi lereng non-convergence terjadi, tidak ada distribusi tegangan yang dapat dicapai untuk memenuhi kriteria Mohr-Coulomb dan kesetimbangan. Iterasi non-convergence diikuti dengan naiknya nilai perpindahan. Biasanya nilai perpindahan mengalami kenaikan yang besar pada saat lereng runtuh dibandingkan pada saat lereng belum runtuh. 


\section{B.3 Kriteria Kemamputerimaan (Acceptable Criteria)}

Lereng tambang terbuka dikatakan dalam keadaan kritis apabila besaran gaya penahan sama dengan gaya penggeraknya atau nilai dari faktor keamanan sama dengan satu, lereng dalam kondisi tidak stabil apabila gaya penggerak lebih besar dari gaya penahannya dan apabila gaya penahannya lebih besar dari gaya penggeraknya maka lereng tersebut dapat dikatakan stabil.

Dalam penentuan nilai ambang batas faktor keamanan yang diperbolehkan dari kestabilan lereng tambang terbuka dibutuhkan kriteria yang dapat mengacu pada nilai-nilai yang dapat dipertanggung jawabkan untuk itu digunakan KEPMEN ESDM 1827 K/30/2018 lampiran ke 2 mengenai pedoman pelaksanaan kaidah teknik pertambangan yang baik.

\section{DATA DAN HASIL PENELITIAN}

\section{C.1 Data}

Tabel 1 merupakan data statistik parameter masukan yang diperoleh dari hasil uji laboratorium sifat fisik dan mekanik batuan, yang selanjutnya analisis statistik dasar dengan menentukan rata-rata dan standar deviasinya diasumsikan berdistribusi normal. Berdasarkan nilai sifat mekanik seluruh batuan menunjukkan batuan yang paling lemah adalah batu lumpur dan batu lempung karbonan.

Tabel 1 Data Statistik Parameter Masukan untuk analisa kestabilan lereng 2 dimensi

\begin{tabular}{lcccccc}
\hline \multirow{2}{*}{ Litologi } & \multicolumn{2}{c}{$\begin{array}{c}\text { Berat Spesifik } \\
\left(\mathrm{kN} / \mathrm{m}^{3}\right)\end{array}$} & \multicolumn{2}{c}{$\begin{array}{c}\text { Kohesi } \\
(\mathrm{kPa})\end{array}$} & $\begin{array}{c}\text { Sudut Gesek Dalam } \\
\text { (Derajat) }\end{array}$ \\
\cline { 2 - 7 } & Rata-rata & Std.Dev & Rata-rata & Std.Dev & Rata-rata & Std.Dev \\
\hline Batu Lumpur & 20,6 & 5,1 & 60 & 15 & 18,1 & 4,5 \\
\hline Batu Pasir & 22,5 & 5,6 & 123 & 30,7 & 30,1 & 7,5 \\
\hline Batu Lumpur pasiran & 21,1 & 5,2 & 72 & 18 & 21,9 & 5,4 \\
\hline Siltstone & 20,6 & 5,1 & 90 & 22,5 & 22,6 & 5,6 \\
\hline Batu Pasir lumpuran & 22,1 & 5,5 & 95 & 23,7 & 26,4 & 6,6 \\
\hline Batu Lempung Karbonan & 21,2 & 5,3 & 37 & 9,2 & 14,1 & 3,5 \\
\hline Batubara & 13,5 & 3,3 & 195 & 48,7 & 43,1 & 10,7 \\
\hline
\end{tabular}

\section{C.2 Analisis 2 Dimensi MEH}

Dalam menentukan SRF dan PK berdasarkan analisis kestabilan lereng dengan metode elemen hingga secara 2 dimensi dengan konsep probabilistik, menggunakan 6 penampang (Gambar 1) yang tersebar di seluruh pit, yang terdiri atas:

- Penampang A-A' (Utara pit)

- Penampang B-B' (Timur pit)

- Penampang C-C' (Barat pit)

- Penampang D-D' (Barat daya pit)

- Penampang E-E' (Selatan bagian dalam pit)

- Penampang F-F' (Selatan bagian luar pit) 


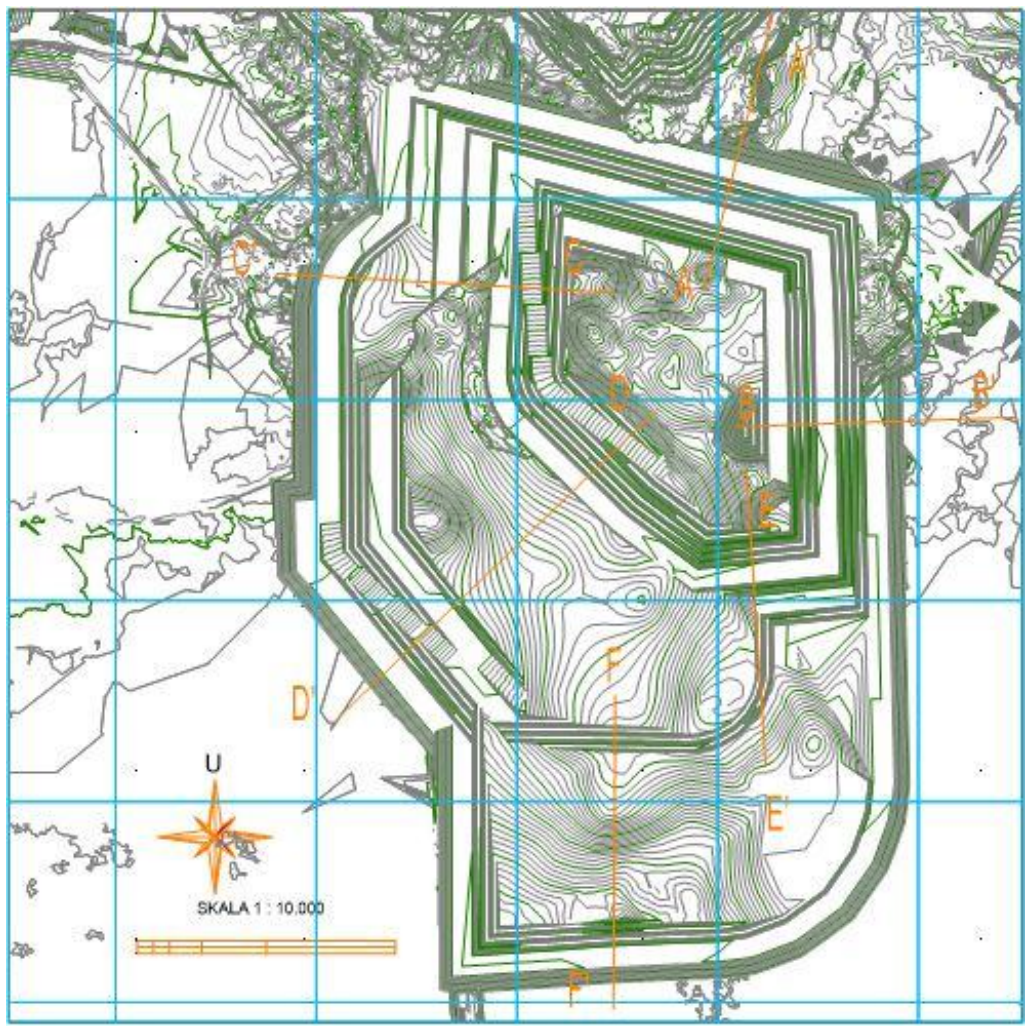

Gambar 1 Peta Penampang Geoteknik PT X

Tabel 2 Rekapitulasi Hasil Analisis 2 Dimensi

\begin{tabular}{|c|c|c|c|c|c|}
\hline \multirow[b]{2}{*}{ Penampang } & \multicolumn{3}{|c|}{$\begin{array}{l}\text { Geometri Lereng } \\
\text { Keseluruhan }\end{array}$} & \multirow{2}{*}{ SRF } & \multirow[b]{2}{*}{ PK (\%) } \\
\hline & $\begin{array}{c}\text { Tinggi } \\
(\mathrm{m})\end{array}$ & $\begin{array}{c}\text { Sudut } \\
\text { (Derajat) }\end{array}$ & $\begin{array}{l}\text { Berm } \\
(\mathrm{m})\end{array}$ & & \\
\hline A-A' & 77,5 & 22 & $9-11$ & 1,26 & - \\
\hline B-B' & 110 & 21 & 10,11 & 1,24 & - \\
\hline C-C' & 38,4 & 26 & 10,11 & 1,36 & - \\
\hline D-D' & 52,0 & 27 & 10,11 & 1,24 & - \\
\hline E-E' & 62,0 & 21 & $8-12$ & 1,40 & - \\
\hline F-F' & 32,7 & 28 & 10,11 & 1,48 & - \\
\hline
\end{tabular}

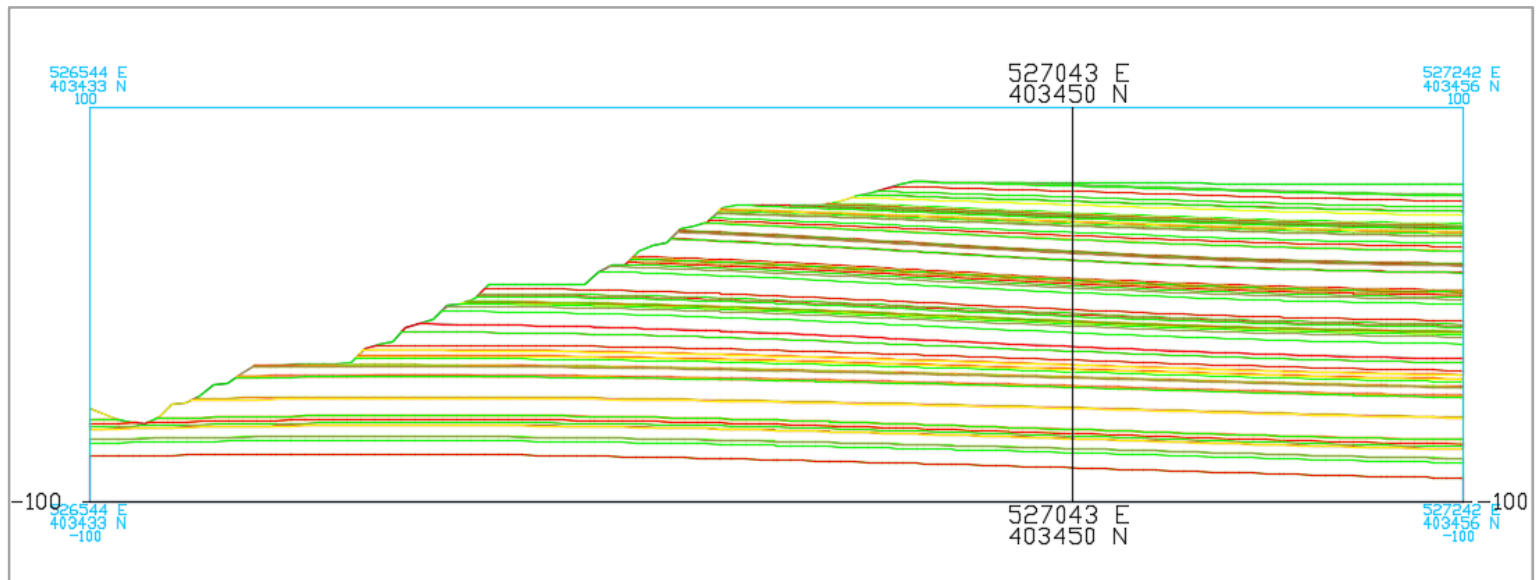

Gambar 2 merupakan contoh model lereng 2 dimensi pada penampang B-B'. 
Hasil analisis 2 dimensi dengan litologi penuh memberikan nilai SRF terendah pada penampang BB' dan D-D' yakni 1,24 dengan nilai PK adalah nol. Pertimbangan juga harus diberikan terhadap penampang B-B' yang memiliki tinggi lereng paling besar, namun sudut lereng selisih 6 derajat dengan penampang D-D' dan penampang A-A' karena memiliki nilai SRF dibawah nilai abang batas kriteria KEPMEN 1827/2018. Hasil ini perlu divalidasi dengan nilai total displacement yang menunjukan lereng mana yang paling kritis.

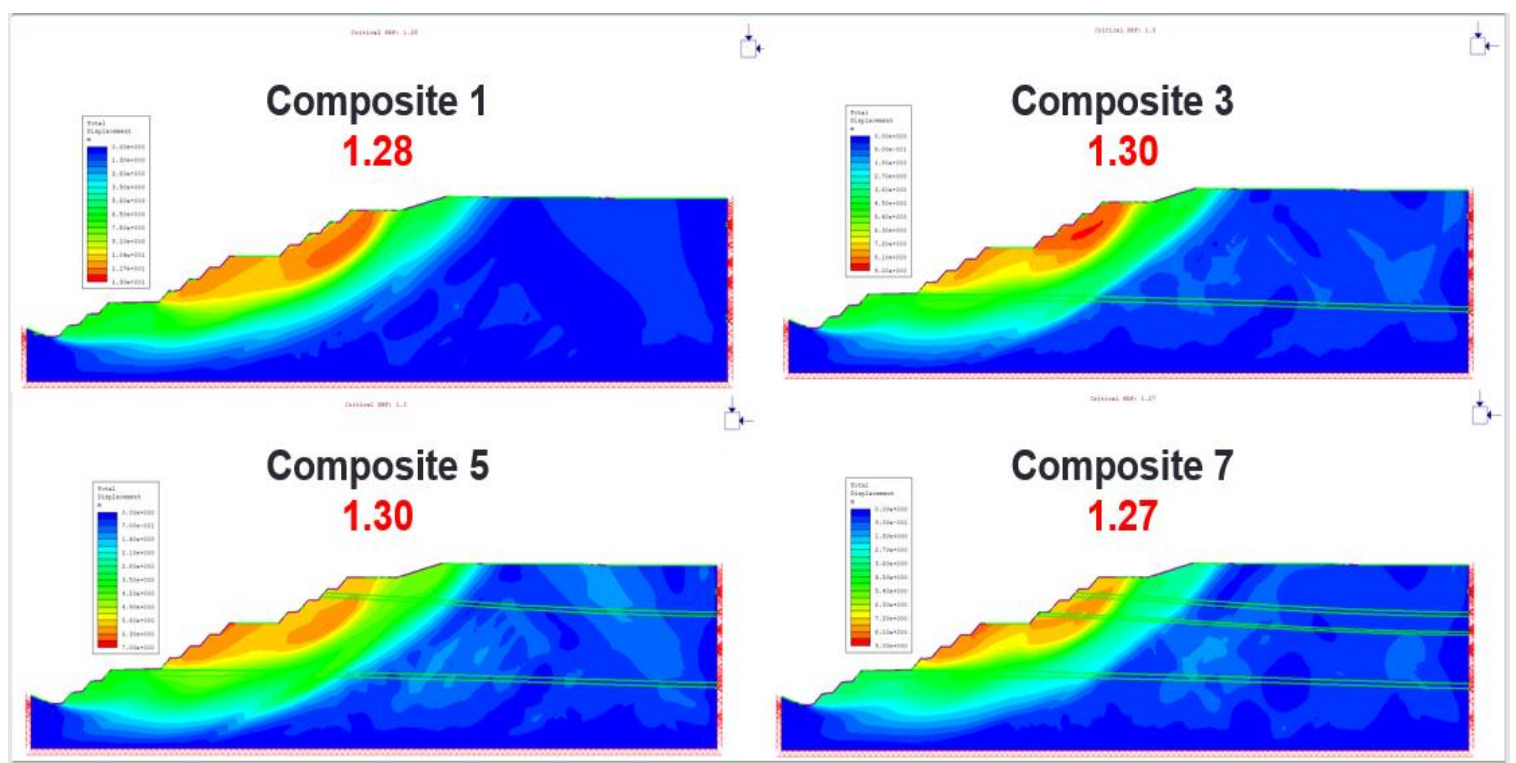

Gambar 3 Contoh Model Hasil Analisis 2 Dimensi Penampang B-B' Hasil Composite

Dengan melakukan pembobotan terhadap nilai properties batuan pada beberapa composite memberikan nilai SRF yang menyimpang dari hasil analisis 2 dimensi yang dilakukan tanpa dilakukannya pembobotan. Untuk penampang B-B' tanpa pembobotan memiliki nilai SRF 1,24 sedangkan hasil composite 7 memberikan nilai yang hampir mendekati nilai sebenarnya yaitu 1,27 bagitu juga pada hasil 7 composite pada penampang D-D' memiliki nilai SRF 1,19 mendekati nilai sebenarnya yaitu 1,24 , hal ini memberikan informasi bahwa dalam melakukan metode pembobotan pada nilai properties semakin banyak jumlah composite maka nilai SRF yang didapatkan akan semakin dekat dengan nilai yang sebenarnya. Dalam hal ini maka perhitungan nilai SRF mengacu pada composite yang paling banyak yaitu 7 karena memiliki nilai SRF yang paling valid.

Tabel 3 Hasil Analisis 2 Dimensi Composite B-B'

\begin{tabular}{ccccc}
\hline \multirow{2}{*}{ Komposit } & \multicolumn{2}{c}{ Faktor Keamanan } & & $\begin{array}{c}\text { Total } \\
\text { Displacement } \\
(\mathrm{m})\end{array}$ \\
\cline { 2 - 4 } & $\begin{array}{c}\text { 6 Node } \\
\text { Uniform }\end{array}$ & $\begin{array}{c}\text { 6 Noded } \\
\text { Graded }\end{array}$ & & \\
\hline 1 & 1,28 & 1,28 & 2 Menit & 11 \\
\hline 3 & 1,3 & 1,3 & 2 Menit & 8,5 \\
\hline 5 & 1,3 & 1,31 & 2 Menit & 6 \\
\hline 7 & 1,27 & 1,27 & 2 Menit & 8,1 \\
\hline
\end{tabular}


Tabel 4 Hasil Analisis 2 Dimensi Composite D-D'

\begin{tabular}{ccccc}
\hline \multirow{2}{*}{ Komposit } & \multicolumn{2}{c}{ Faktor Keamanan } & Waktu & $\begin{array}{c}\text { Total } \\
\text { Displacement } \\
(\mathrm{m})\end{array}$ \\
\cline { 2 - 5 } & $\begin{array}{c}\text { 6 Node } \\
\text { Uniform }\end{array}$ & $\begin{array}{c}\text { 6 Noded } \\
\text { Graded }\end{array}$ & & \\
\hline 1 & 1,31 & 1,30 & 2 Menit & 7,2 \\
\hline 3 & 1,29 & 1,28 & 2 Menit & 3,6 \\
\hline 5 & 1,3 & 1,28 & 2 Menit & 5,6 \\
\hline 7 & 1,19 & 1,20 & 2 Menit & 2,9
\end{tabular}

Dalam analisis 2 dimensi dengan metode elemen hingga (MEH) digunakan 6 node karena memiliki jumlah node tertinggi dalam penggunaannya. Semakin tinggi jumlah node yang digunakan didalam perhitungan maka hasil yang didapat akan semakin akurat, karena tingkat kerapatan data analisa akan semakin rapat tetapi perhitungan akan memakan waktu yang lebih lama karena jumlah perhitungan akan semakin meningkat. Pada analisis 3 dimensi dengan metode elemen hingga (MEH) digunakan 10 node karena hasil yang didapat mendekati hasil analisa yang dilakukan secara 2 dimensi dengan penggunaan 6 node untuk itu hasil yang didapat valid.

\section{C.3 Analisis 3 Dimensi MEH}

Analisis yang dilakukan secara 3 dimensi dengan metode elemen hingga (MEH) digunakan untuk menentukan posisi lereng yang paling kritis dan nilai SRF yang didapatkan perlu divalidasi secara 2 dimensi. Dalam hal penentuan posisi kritis, nilai SRF dan total displacement yang dilakukan secara 3 dimensi maka digunakan 7 composite karena informasi yang diberikan oleh anlisis secara 2 dimensi membuktikan bahwa semakin banyak jumlah composite maka nilai SRF yang didapatkan akan mendekati nilai yang sebenarnya sehingga hasil yang didapatkan lebih valid.
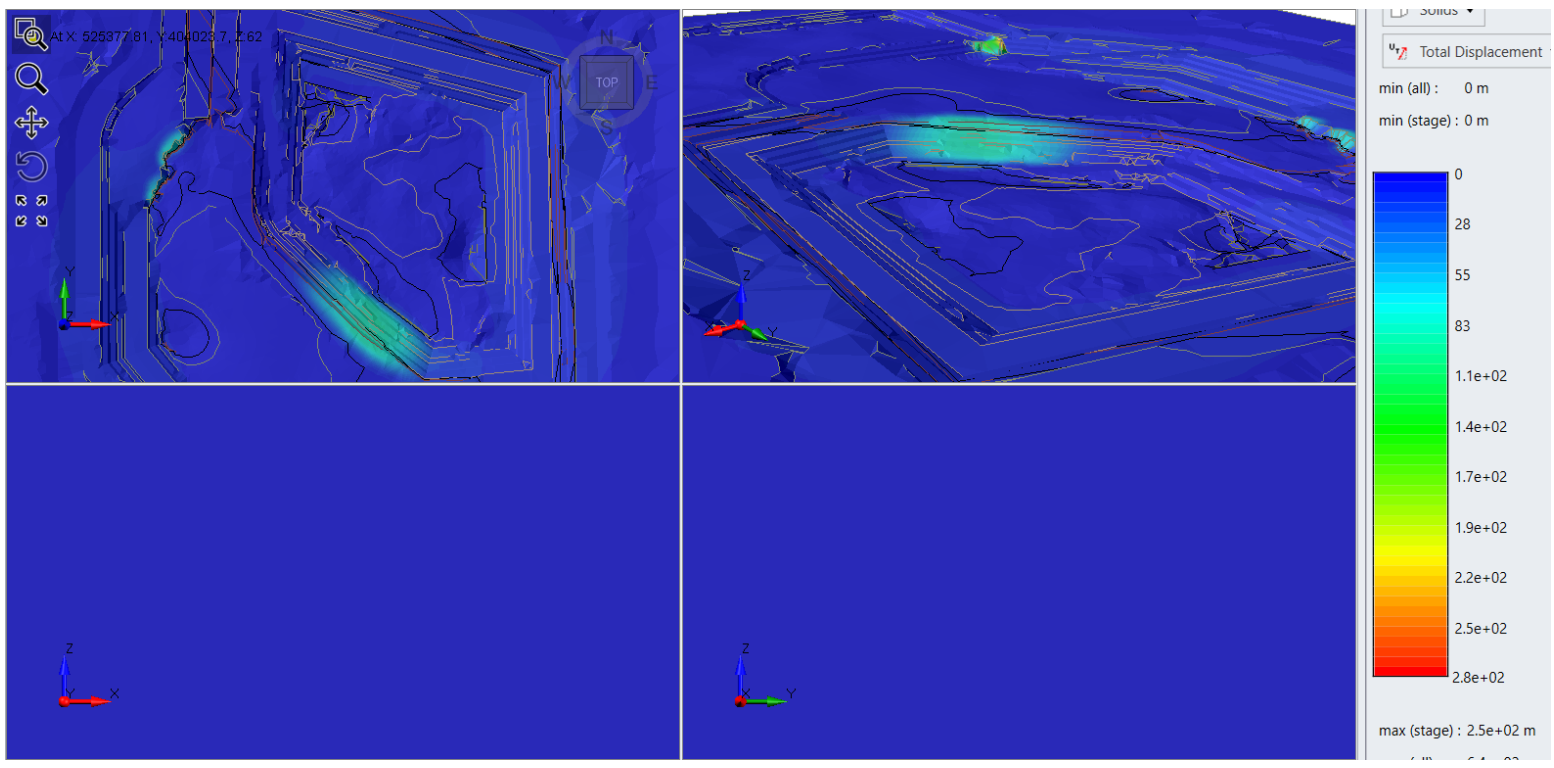

Gambar 4 Hasil Analisis 3D MEH 7 composite

Posisi kritis hasil analisis 3 dimensi metode elemen hingga pada 7 composite menunjukan bahwa penampang D-D' merupakan zona yang paling berbahaya karena memiliki nilai total displacement dan nilai SRF yang didapatkan sebesar 1,24 atau sama dengan nilai SRF hasil analisis 2 dimensi 
pada penampang D-D' yang tidak dilakukan pembobotan, sehingga dapat dikatakan nilai SRF hasil analisis 3 Dimensi 7 composite sesuai atau tervalidasi secara 2 dimensi.

Tabel 5 Hasil Analisis 3 Dimensi Berbagai Composite

\begin{tabular}{ccccc}
\hline Komposit & $\begin{array}{c}\text { 10 Node } \\
\text { Graded }\end{array}$ & Waktu & $\begin{array}{c}\text { Lokasi } \\
\text { Penampang } \\
\text { Kritis }\end{array}$ & $\begin{array}{c}\text { Total } \\
\text { Displacement } \\
(\mathrm{m})\end{array}$ \\
\hline 1 & 1,32 & 16 Jam & D, B, A & 21 \\
\hline 3 & 1,31 & 32 Jam & D & 60 \\
\hline 5 & 1,30 & 44 Jam & D & 33 \\
\hline 7 & 1,24 & 46 Jam & D & 70 \\
\hline
\end{tabular}

\section{C.4 Penentuan Nilai Displacement dan Pengaruh Pembobotan}

Nilai total displacement selain dapat memberikan informasi posisi daerah yang paling kritis pada analisis 3 dimensi juga dapat menentukan kondisi lereng saat runtuh atau non-convergence, dimana pada kondisi ini terjadi kenaikan terhadap nilai displacement yang signifikan saat faktor penurunan kekuatan batuan dinaikan secara bertahap.

Dalam menentukan kondisi lereng yang dianggap paling kritis digunakan 3 parameter yaitu:

- Nilai SRF hasil analisis kestabilan

- Jumlah displacement

- Geometri lereng keseluruhan

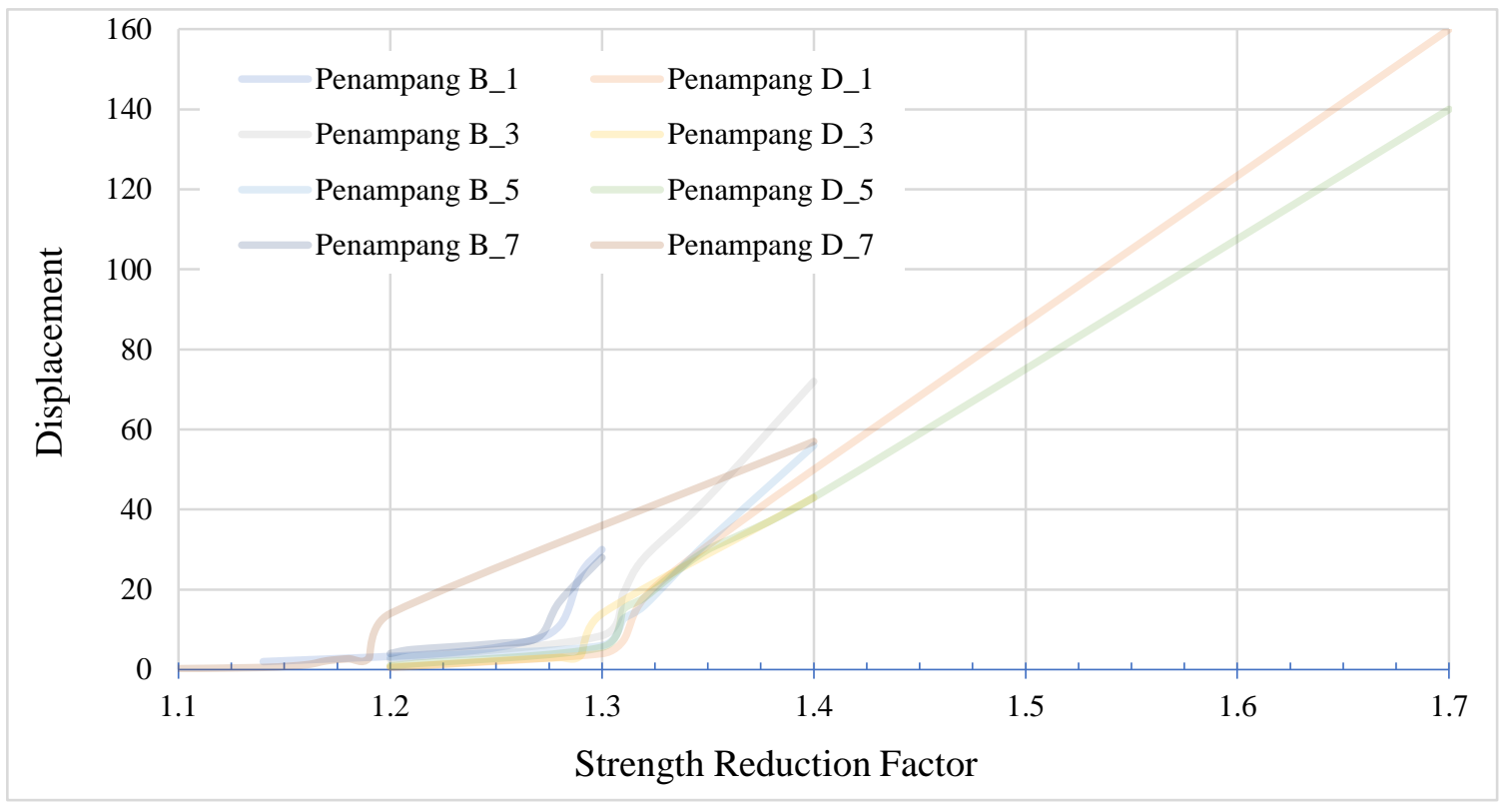

Gambar 5 Grafik SRF VS Total Displacement 2 Dimensi 


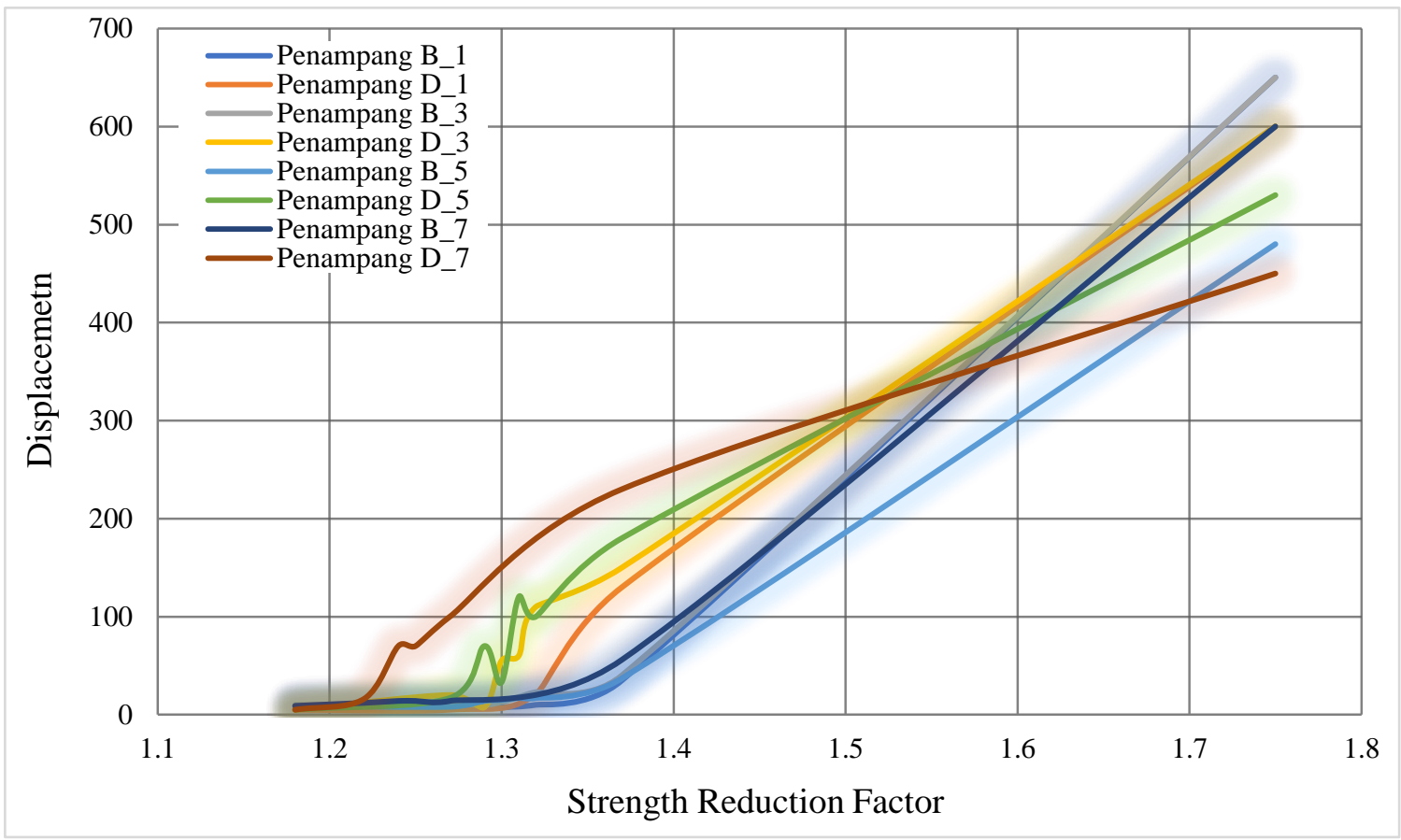

Gambar 6 Grafik SRF VS Total Displacement 3 Dimensi

Berdasarkan grafik perbandingan nilai SRF dengan total displacement memberikan informasi bahwa nilai dari total displacement hasil analisis 3 dimensi cenderung lebih besar dibandingkan hasil analisis 2 dimensi dan nilai critical SRF terjadi saat nilai displacement mengalami kenaikan yang cukup signifikan, ini menandakan terjadi pergerakan node yang besar dan dengan asumsi ini lereng dikatakan non-convergence atau runtuh dengan kata lain node akan bergerak lebih besar saat lereng runtuh dibandingkan saat lereng belum runtuh.

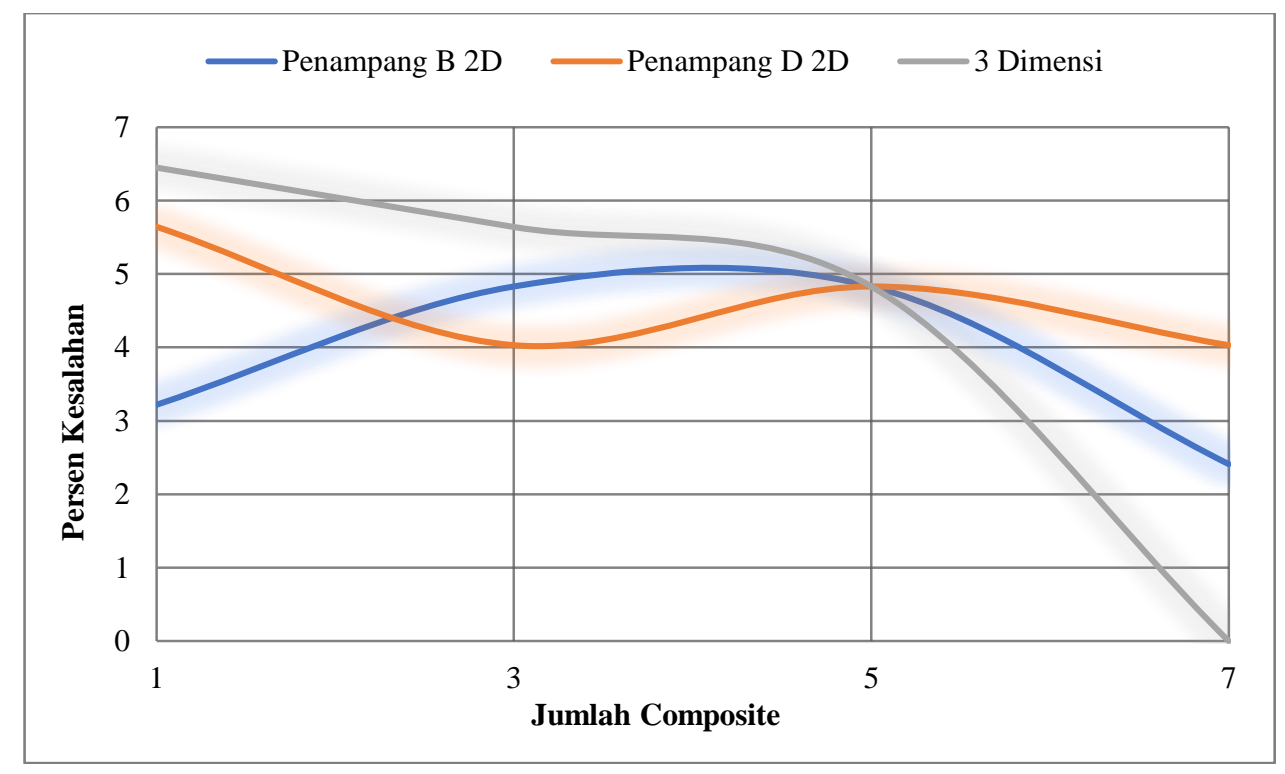

Gambar 7 Jumlah Composite VS Persen Kesalahan

Grafik perbandingan jumlah composite yang digunakan dengan persen kesalahan yang mengacu pada hasil analisis yang dilakukan tanpa pembobotan, memberikan informasi bahwa semakin banyak jumlah composite yang digunakan dalam perhitungan maka persen kesalahan yang 
didapatkan cenderung lebih kecil atau dengan kata lain nilai yang didapatkan semakin mendekati nilai yang sebenarnya sehingga hasil analisis yang didapatkan valid.

\section{KESIMPULAN}

Berdasarkan hasil penelitian dapat disimpulkan sebagai berikut:

- Hasil analisis kestabilan lereng menggunakan metode elemen hingga 2 dimensi tanpa komposit memberikan nilai SRF paling rendah pada penampang D-D' dan B-B' yaitu sebesar 1,24 .

- Penentuan 7 komposit batuan memberikan nilai FK yang paling valid dengan perbedaan nilai SRF sebesar 0,03 untuk penampang B-B' atau $2,4 \%$ dan 0,05 atau $4 \%$ untuk penampang D-D' dari nilai sebenarnya.

- Hasil analisis kestabilan lereng 3 dimensi memberikan nilai SRF sebesar 1,32 pada 1 composite; 1,31 pada 3 composite; 1,30 pada 5 composite; dan 1,24 pada 7 composite dengan penampang D-D' yang dianggap paling kritis.

- Nilai total displacement hasil analisis 3 dimensi lebih besar dibandingkan hasil analisis 2 dimensi.

\section{UCAPAN TERIMA KASIH}

Penulis menyampaikan terima kasih yang sebesar-besarnya kepada PT X yang telah memfasilitasi dalam pengambilan data lapangan, serta Laboratorium Komputasi tambang FTKE Universitas Trisakti yang telah memfasilitasi penulis dalam menggunakan perangkat lunak yang digunakan dalam permodelan data penelitian.

\section{DAFTAR PUSTAKA}

Ardhi, H.A.; Azizi, M.A.; Marwanza, I.; Hartami, P.N.; Nugroho, B.; Saptono, S. 2017. Perbandingan analisis stabilitas lereng metode kesetimbangan batas dengan metode elemen hingga menggunakan pendekatan probabilistik. Seminar Nasional Geomekanika 4 (SNG4) Padang: 179-185.

Azizi, M.A.; Kramadibrata, S.; Wattimena, R.K.; Sidi, I.D. 2013. Probabilistic analysis of physical models slope failure. International Symposium on Earth Science and Technology, CINEST 2012, Procedia Earth and Planetary Science 6: 411-418.

Azizi, M.A.; Kramadibrata, S.; Wattimena, R.K.; Sidi, I.D. 2014. Risk assessment of open pit slope design at PT Adaro Indonesia. Indonesian Mining Journal 17 (3): 113-121.

Azizi, M.A.; Marwanza, I.; Hartanti, N.A.; Anugrahadi, A. 2018. Three dimensional slope stability analysis of open pit limestone mine in Rembang District, Central Java. International Conference on Earth, Science, Mineral and Energy (ICEMINE) 2018, IOP Conf. Ser.: Earth Environ. Sci. (212) 012035, doi:10.1088/1755-1315/212/1/012035.

Azizi, M.A.; Marwanza, I.; Hartanti, N.A.; Aulianissa, A.; Anugrahadi, A 2019. The influence of number of grid points and radius increments in determining safety factor and estimated sliding volume on three dimensional slope stability analysis. The 2nd Mineral Processing and Technology International Conference, IOP Conf. Ser.: Mater. Sci. Eng. (478) 012041, doi:10.1088/1757-899X/478/1/012041.

Cheng, Y.M. and Yip, C.J. 2007. Three-Dimensional Asymmetrical Slope Stability Analysis Extension of Bishop's, Janbu's, and Morgenstern-Price's Techniques, ASCE Journal of Geotechnical and Geoenvironmental Engineering, 133(12), 1544-1555. https://doi.org/10.1061/(ASCE)10900241(2007)133:12(1544).

Contreras, L.F.; LeSueur, R.; Maran, J. 2006. A case study of risk evaluation at cerrejon mine. International Symposium on Stability of Rock Slopes in Open Pit Mining and Civil 
Engineering, Cape Town, 3-6 April 2006. Johannesburg: The South African Institute of Mining and Metallurgy.

Department of Industry, Innovation and Science Australia. 2016. Risk management: leading practice sustainable development program for the mining industry. Australia: Commonwealth of Australia.

Hoek, E..1987. Faktor of Safety and Probability of Failure, Chapter 8 - Practical Rock Engineering.

Hoek, E..2000. Faktor of Safety and Probability of Failure, Chapter 8 - Practical Rock Engineering (revision).

Hoek, E..2006. Faktor of Safety and Probability of Failure, Chapter 8 - Practical Rock Engineering (revision).

Kepmen ESDM No 1827/K/30/MEM/2018 Tentang Pedoman Pelaksanaan Kaidah Teknik Pertambangan Yang Baik. 2018. Lampiran II Tentang Pedoman Pengelolaan Teknis Pertambangan.

Kramadibrata, S.; Wattimena, R.K.; Sidi, I.D.; Azizi, M.A. 2012. Open pit mine slope stability and uncertainty. ISRM Regional Symposium - 7th Asian Rock Mechanics Symposium, Seoul,1519 October. Korea: International Society for Rock Mechanics and Rock Engineering.

Kramadibrata, S.; Wattimena, R.K.; Sidi, I.D.; Wicaksana, Y.; Azizi, M.a. 2013. Physical modeling and simulation of slope failure by means of centrifuge acceleration. ISRM International Symposium - EUROCK 2013, Wroclaw, 23-26 October. Poland: International Society for Rock Mechanics and Rock Engineering.

Masagus Ahmad Azizi \& Rr Harminuke E. Handayani. 2011. Karakterisasi parameter masukan untuk analisis kestabilan lereng tunggal (studi kasus di PT. Tambang Batubara Bukit Asam Tbk. Tanjung Enim, Sumatera Selatan). Prosiding Seminar Nasional AVoER ke-3, 26-27 October 2011. Palembang: Fakultas Teknik Universitas Sriwijaya.

Read, J. \& Stacey, P. 2009. Guidelines for open pit slope design. Collingwood: CSIRO publishing.

Rocscience, Inc. 2019. Slide 2 online help. https://www.rocscience.com/help/slide2. (Accessed on 8 March 2019)

Tapia, A.; Contreras, L.F.; Jefferies, M.; Steffen, O. 2007. Risk evaluation of slope failure at the chuquicamata mine. In Y Potvin (ed.), Proceedings of the 2007 International Symposium on Rock Slope Stability in Open Pit Mining and Civil Engineering, Australian Centre for Geomechanics, Perth: 477-495.

Terbrugge, P.J.; Wesseloo, J.; Venter, J.; Steffen, O.K.H. 2006. A risk consequence approach to open pit slope design. The Journal of The South African Institute of Mining and Metallurgy, Vol.106.

Wattimena, R.K.; Kramadibrata, S.; Sidi, I.D.; Azizi, M.A. 2012. Probabilistic analysis of single bench using new slope stability curves. ISRM Regional Symposium - 7th Asian Rock Mechanics Symposium, Seoul, 15-19 October. Korea: International Society for Rock Mechanics and Rock Engineering.

Wattimena, R.K.; Kramadibrata, S.; Sidi, I.D.; Azizi, M.A. 2013. Developing coal pillar stability chart using logistic regression. International Journal of Rock Mechanics \& Mining Sciences 58 (2013): 55-60. 